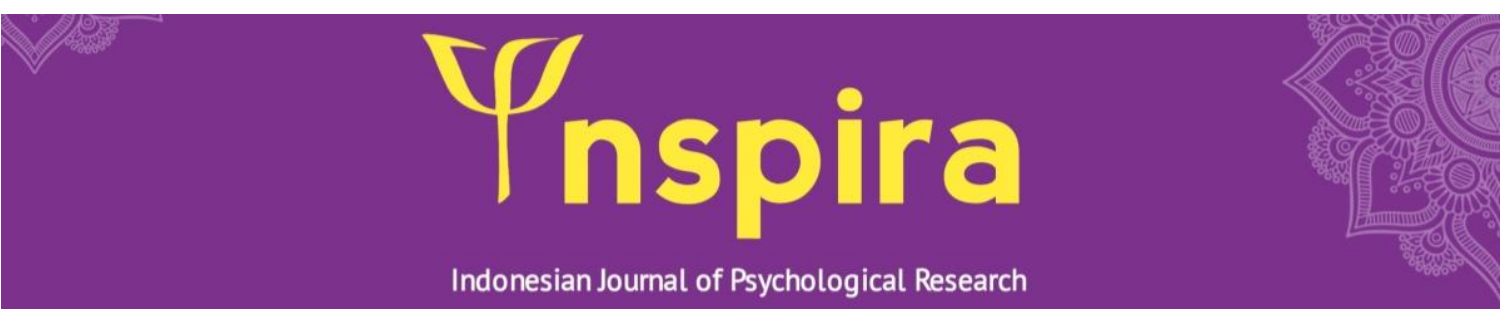

\title{
The religiosity of Hijrah adolescence in Muslimah Aceh Fillah Community Aceh Tamiang Indonesia
}

Nadya Afriyanti ${ }^{1}$, Dedy Surya ${ }^{2 区}$

${ }^{12}$ Department of Islamic Guidance and Counseling, Institut Agama Islam Negeri Langsa, Aceh, Indonesia.

\section{${ }^{凶}$ Corresponding author:}

Dedy Surya (email: dedysurya@iainlangsa.ac.id)

\begin{abstract}
In the influx of hedonism and consumptive culture due to the development of communication and information technology, extraordinary hijrah flows from the young generation of Indonesia. This study aims at the religiosity of adolescents experienced by hijrah adolescents through 5 dimensions of religiosity: experiential, ritualistic, ideological, intellectual, and consequential. This study involved 5 Muslimah Aceh Fillah members selected by purposive sampling techniques using a qualitative approach. In-depth interview techniques and participatory observations obtained the data. In addition to engaging its members, the researchers also took parental data from the study subjects to get a comprehensive picture. Then, the data is analyzed through 3 stages: data reduction, data presentation, and conclusion. The results showed that the religiosity of hijrah adolescents is expressed in various dimensions. The most significant change felt by community members is thought in an intellectual dimension that implies an improvement in the other aspect of religiosity.
\end{abstract}

\section{How to cite (APA $7^{\text {th }}$ Edition)}

Afriyanti, N. \& Surya, D. (2020). The religiosity of Hijrah adolescence in Muslimah Aceh Fillah Community Aceh Tamiang Indonesia. INSPIRA: Indonesian Journal of Psychological Research, 1(2), 43-48. https://doi.org/10.32505/inspira.v1i2.2850

\section{Article History:}

Received: August 20, 2020

Revised: September 6, 2020

Accepted: November 7, 2020

Published: December 28, 2020

\section{Keyword:}

Aceh; adolescence; community; Hijrah; religiosity

This is an open-access article distributed under the Creative Commons Attribution License, which permits unrestricted use, distribution, and reproduction in any medium provided the original work is properly cited. This is enabled under the terms of attribution and noncommercial usage of the material. (C2020 by Nadya Afriyanti \& Dedy Surya. 


\section{INTRODUCTION}

Adolescence has a critical phase that determines its success is entering the adult phase. It is called the crucial phase because, in this phase, the youth are required to prepare themselves through their potential to face the challenges of their lives in the upcoming phase of development (Jannah, 2016). If they can prepare themselves well, then they can meet the problems of life naturally without concern. However, if they fail to develop themselves, their life in the adult phase will run with problems without adaptability and good problem-solving skills.

The emerging phenomenon is the tendency of adolescents to show attitudes and ignorance in the context of religion (Thobroni, 1993). It is easy to get news of teenagers getting drunk, using drugs, committing theft, rape, even murder. It was coupled with the development of information and communication technology, allowing teenagers to expand their delinquency in the real world and penetrate the virtual world. Gambling and online prostitution committed by teenagers is one of the evidence of the spread of crime that occurs in this digital age. This shows that the implementation of religion is not integrated between knowledge, attitudes, and behaviors in daily life.

Uniquely, during the teenage crime that was later resonated by the sophistication of communication and information media, the phenomenon of hijra emerged among young Indonesians. This phenomenon of hijrah is defined as the process of changing behavior that is not following sharia to conduct by sharia (Amna, 2019). Today there are many hijrah communities formed by artists and celebrities. The community consists of many famous artists who have done hijrah. In addition to the communities, the hijrah millennials phenomenon is also supported by many hijrah events (Alamsyah, 2019) to increase religiosity.

Research on adolescents' religiosity in the Indonesian hijra community has been conducted several times, among others by Paninten \& Indrawati (2020), which reviews the linkage of social support to the religiosity of members of the Cah Hijrah Semarang community. This research showed that social support has an influence on the religiosity of adolescents in the hijra community. Dilawati (2020) highlighted the religiosity of the Hijrah Youth Shift community at the Great Mosque of Trans Studio Mall Bandung. This study mentioned that the study activities given to the community positively affect the religiosity of youth.

Some research that has been done related to religiosity in the hijrah community is still limited to seeing the changes in religiosity that occur in members of the hijrah community in general. Meanwhile, differences in religiosity in each dimension have not been studied in depth. This article aims to review changes in each dimension of religiosity as mentioned by Glock \&Starck (1965) teenagers who emigrated to the Muslimah Aceh Fillah community, Aceh Tamiang, Indonesia (MAF)

\section{RESEARCH METHOD}

The research was conducted with a qualitative approach with a case study pattern. This study involved five members of MAF (Mela, Dea, Dana, Alfi, and Irna) selected through purposive sampling techniques with criteria: 1) have an age range of 12-20 years; 2) have been following studies in MAF for at least three months. The current study also involved parents of each research subject as informants to get more information. 
The data is collected in 3 (three) ways, namely; 1) observation, 2) interview, and documentation. The observation used anecdotal records, i.e., observing and recording unique activities during observation (Arikunto, 2010). The interview was naturalistic interviews, interviewing speakers conducted informally in talking or chatting with various open questions to find the in-depth and complete information to answer the research questions (Nazir, 1999). The documentation collected written materials or objects related to a particular event or activity (Suprayogo \&Tobroni, 2003). Then the data is analyzed with techniques developed by Miles \&Huberman (2007) through the stages of data collection, data reduction, data presentation, and conclusion or verification.

\section{RESULT}

Based on information obtained from the five informants, it was found that after participating in activities organized by MAF, they experienced an increase in religiosity. Changes in experiential dimension occur after obtaining explanations through recitation activities, as explained by Mela:

"Dulu Mela sempat melakukan hal syirik seperti menolak bala atau menolak sesuatu hal yang buruk biasanya menurut orang-orang di sekitar Mela harus membuat Bubur Merab Putih yang diletakekan di persimpangan jalan sampai bubur tersebut tidak ada lagi. Namun setelah Mela mengikuti pengajian di MAF, Mela menjadi tahu babwa kegiatan itu adalab perbuatan yang syirik dan Alhamdulillah sekarang Mela tidak melakukan hal itu lagi". (I used to do shirk things such as refusing reinforcements or rejecting something bad, according to people around me, I should make "Merah Putih" porridge that was placed at the crossroads until the porridge no longer exists. However, since I am joining MAF, I become aware that the activity is a shirk and praise Allah, now I do not do that anymore)

From the case that Mela experienced, it appeared that there is a change that Allah is the protector of all things, so the practice of distancing himself from the reinforcements by making porridge placed at the crossroads she now left.

It is also the same as Dea's, who left her tradition to bring scissors and garlic as a protector when pregnant. This change occurs because they believe that believing there is a power other than the power of God is a shirk and is a grave sin.

Irna also explained the change of her belief:

"... kalau dulu saya suka ngeluh kalau diberikan ujian sama Allah. Merasa padahal saya sudah ibadah tetapi Allah masih kasih kami ujian dan buat saya malas untuk ibadah karena kami rasa ibadah kami percuma. Ternyata, saat kita diuji itu karena Allah tabu babwa kita mampu dan Allah sayang sama kita. Kitanya saja yang kurang bersyukur, harusnya kita introspeksi diri apa yang kurang dari diri kita." (... I used to like to complain if I was tested by Allah. I feel even though I have worship but He still tested me. It made me lazy for worship because we think our worship is useless. As it turns out, when we are tested it is because He knows that we are capable and He loves us. We are the less grateful, we should introspect ourselves what is less than we are.)

This is just as Dana and Alfi felt that they always wondered when they felt many exams before they joined this community. The change of experiential dimension that they think in the form of submission to the provisions outlined by Allah and convinced that the difficulty they feel was a form of Allah's affection see the extent of the quality of their faith.

In the ritualistic dimension, MAF targets consistency in carrying out worship activities that will be evaluated once a week at each study meeting. Some of the assessed activities are five times 
prayer (every day), congregational prayer (at least two times per day), Dhuha prayer (at least two times per week, Tahajjud prayer (at least two times per week), Hajat prayer (at least one time per week), fasting on Monday and Thursday (at least one time per week), reading the Qur'an (minimum one juz per week), memorizing the Qur'an (minimum 1 verse per week), memorization of prayers (minimum one prayer per week), alms (every day), attending studies (at least one time per week), and silaturrahim (at least one time per month).

Evaluation of worship activities increases consistency to the ritual of worship of the informant. Irna explained: "... awalnya shalat suka ditunda-tunda. Sekarang menjadi lebih tepat waktu untuk mengerjakannya. Rasanya ga mau ketinggalan waktu shalat. Juga sudah rajin puasa sunnah, dan sekarang sudah memakai pakaian yang menutup aurat..." (at first, I like postponing prayer. Now it's becoming more on time to do it. I feel hard to miss the prayer. I also feel more diligent in sunnah fasting, and already cover my awrah)"

It is also felt just as Dea said, "... kalau dulu setiap kami shalat, suka-suka hati kami. Tapi kalau sekarang, bilang sama diri sendiri kalau shalat harus lima waktu karena itu adalah kewajiban... (I used to prayer only when I want, but now, I tell to myself that I should pray completely in five times because it is an obligation)." Even by following this community, Dana has now used a purdah.

Through the evaluation activities conducted by this community, the members who were starting hijrah became accustomed to performing mandatory worship routines and sunnah. While for members who already have an excellent religious understanding, this activity helps them perform worship.

Ideological dimension was felt in all informants about the sense of a restless heart moments before performing worship and gaining inner peace after completing worship. As Alfi said: "Sekarang jika tidak shalat, gelisah hati. Tenang kalau sudah melaksanakan shalat". ("Now if I do not pray, I feel a restlessness in my heart. I feel tranquil." The consistency in practicing prayer has caused a sense of peace of mind when doing worship.

The dimension the most changes was the intellectual dimension when the individual had known the commands and prohibitions of religion. Through routine study activities carried out, the five informants felt a significant change in their religious intellectual. Regular meetings conducted by this community alternately discuss tawhid, laws, morals, and the history of the prophet and his followers. In addition, the study also provides time to consult directly the presenters related to the problems that are being faced.

Changes in the consequential dimensions also occurred in this community members. The interview with the informant's parents concluded a change in behavior in their child after joining the community. Dewi, Alfi's mother, said 'Tbu libat setelab dia ikut MAF ini banyak perubahannya dari mulai shalatnya. Terus, cara berpakaian dia di rumah, dari yang biasanya dia masih suka pakai celana kalau sekarang lebib sopan. (I saw many changes when she joined the community, like her consistency in prayer. And then, the way she dresses at home. She usually likes to wear pants. Now she looked more polite)." In addition to behavior, character changes also occur, as Ana, Mela's mother, feels that her daughter is now becoming more friendly and polite to others. A similar answer was also given by three other parents who supported their children to join the community because their child experienced a positive behavior change. 


\section{DISCUSSION}

In contrast to Afiatin's research (1998) which stated that the ritualistic dimension became the highest dimension, this study found that the dimension of knowledge became the most central dimension.

This study found that the efforts made by MAF are to form the obedience of its members who want to do hijrah to religious sharia. This is in line with Zahara, Wildan, \& Kamariah's (2020) research that the hijra community seeks to form a new identity of its members as religious people who obey the rules of religion.

The study findings also reinforced the Mayasari (2014) view, which states that religiosity grows from the closeness of interaction with God. These interactions give birth to calmness and a positive effect on the individual self.

This study has revealed the positive effect of the community in improving the religiosity of its members, following the conclusion of Irmansyah (2020), which stated that the hijrah community has a positive impact on the younger generation who follow it through changes in behavior that are more salih and stylish following the progress of the times but still sharia.

\section{CONCLUSION}

This research showed the religiosity of hijah adolescence in various dimensions. Of all these dimensions, the dimension of intellectual plays an essential role in shaping religiosity. A good understanding of religion will give birth to reasonable religious beliefs and ritual practices. The spiritual practice leaves a deep sense of feeling for the perpetrator, which will ultimately affect them. To the impact, the formed religiosity has also been influenced the adolescent environment that manifested in their behavior.

\section{REFERENCES}

Afiatin, T. (1998). Religiusitas remaja: Studi tentang kehidupan beragama di Daerah Istimewa Yogyakarta. Jurnal Psikologi, 25(1), 55-64.

Alamsyah, I. E. (2019). Fenomena hijrah kaum milenial. https://www.republika.co.id/berita/puyv6k349/fenomena-hijrah-kaum-milenial

Amna, A. (2019). Hijrah artis sebagai komodifikasi agama. Jurnal Sosiologi Reflektif, 13(2), 331-350. DOI: https://doi.org/10.14421/jsr.v13i12.1531

Arikunto, S. (2010). Prosedurpenelitian: Suatu pendekatan praktek. Rineka Cipta

Glock, C. Y., \& Stark, R. (1965). Religion and society in tension. Rand McNally.

Jannah, M. (2017). Remaja dan tugas-tugas perkembangannya dalam islam. Psikoislamedia: Jurnal Psikologi, 1(1), 243-256.

Mayasari. R. (2014). Religiusitas Islam dan kebahagiaan (Sebuah telaah dengan perspektif psikologi). Al-Munzir, 7(2), 81-100.

Miles, M. B. \& Huberman, A. M. (2007). Qualitative data analysis. (terjemahan). UI Press.

Nazir, M. (1999). Metode penelitian. Ghalia Indonesia.

Paninten, G. A., \& Indrawati, E. S. (2020). Hubungan antara dukungan sosial teman sebaya 
dengan religiusitas pada Komunitas Cah Hijrah Semarang. Jurnal EMPATI, 9(4), 262-279. Retrieved from https://ejournal3.undip.ac.id/index.php/empati/article/view/28944

Suprayogo, I \& Tobroni. (2003). Metodologi penelitian sosial agama. PT. Remaja Rosdakarya

Zahara, M. N., Wildan, D., \& Komariah, S. (2020). Gerakan hijrah: Pencarian identitas untuk muslim milenial di era digital. Indonesian Journal of Sociology, Education, and Development, 2(1), 52-65. https://doi.org/10.52483/ijsed.v2i1.21 